\title{
Extraction And Characterization Of Cellulose Whiskers From The Brazilian Semiarid Northeast: Caroá And Macambira Fibers
}

\section{Murilo J. P. Macedo ( $\sim$ murilojpmacedo@gmail.com )}

Graduation Program in Materials Science and Engineering (PPCEM) - UFPB https://orcid.org/00000001-9273-1377

\section{Amelia S. F. Santos}

Graduation Program in Materials Science and Engineering (PPCEM) - UFPB

\section{Juliano E. Oliveira}

Materials and Biosystems Laboratory, Department of Engineering (DEG) - UFLA

\section{Eliton S. Medeiros}

Graduation Program in Materials Science and Engineering (PPCEM) - UFPB

\section{Research Article}

Keywords: Acid hydrolysis, caroá, cellulose whiskers, fiber modification, macambira, thermal characterization.

Posted Date: February 14th, 2022

DOl: https://doi.org/10.21203/rs.3.rs-746503/v1

License: (1) This work is licensed under a Creative Commons Attribution 4.0 International License. Read Full License 


\section{Abstract}

Cellulose nanocrystals were successfully extracted from caroá (Neoglaziovia variegata) and macambira (Bromelia laciniosa) fibers, which are native plants from the semi-arid Caatinga biome in Northeastern Brazil. Fibers were submitted to alkaline and bleaching treatments prior to sulfuric acid extraction. Morphology and chemical composition (holocellulose and cellulose content) of fibers were determined by scanning electron microscopy and chemical analysis, respectively. Cellulose nanocrystal structure, crystallinity and thermal stability were determined respectively by atomic force microscopy and thermogravimetric analysis. Results show that mercerization followed by bleaching were able to remove waxes and amorphous regions. Caroá fibers required one mercerization and three bleaching steps while macambira needed one mercerization and two bleaching steps prior to nanocrystal extraction. Alkaline treated and bleached samples had lower thermal stability as compared to untreated fibers due to removal of lignin and increased surface area. Caroá and macambira are renewable sources of cellulose nanocrystals with potential applications as reinforcements to nanocomposites.

\section{Introduction}

Vegetable fibers are typically composed of cellulose, hemicellulose, and lignin. The chemical composition of these fibers depends upon factors such as age, origin and mode of extraction (Bledzki and Gassan 1999). Despite the use of lignocellulosic fibers over the last four decades, these materials have been recently revisited aiming at production of cellulose nanocrystals. Due to their reduced size, light weight, high surface area, high specific mechanical properties and reactivity are among the outstanding properties of cellulose nanocrystals that can be extracted from plants via several chemical processes such as acid hydrolysis, which is one of the most widely used (Li et al. 2009; Medeiros et al. 2008; Orts et al. 2005; Puglia et al. 2017; Rosa et al. 2010; Sain et al. 2017).

Lignocellulosic fibers are used as reinforcement in polymers due to their potential to improve the composites' properties (Thakur and Thakur 2014). Usually, most fibers need to be modified prior to use, e.g., mercerization and bleaching treatments used to remove non-cellulosic materials such as lignin and hemicelluloses (Fiore et al. 2015), once these non-cellulosic components undergo degradation during nanocrystal isolation and need to be removed before acid hydrolysis (Colom et al. 2003; Satayanarayana et al. 2007; Spagnol et al. 2012; Teixeira et al. 2011).

In natural fibers, cellulose is found in crystalline and amorphous regions of plant cells. Under hydrolysis or other chemical or sonochemical treatment, cellulose from amorphous regions readily degrades while the crystalline regions give rise to nanocrystals or whiskers, which are later lyophilized and stored to be used, e.g., in composite materials (Rosa et al. 2010; Tadmor and Gogos 2006).

Caroá (Neoglaziovia variegata) and macambira (Bromelia laciniosa) are two native plant species of Brazilian semiarid, known as the Caatinga biome, whose natural resources still need to be scientifically studied and economically exploited. Widespread and abundant as they are, these two plant species 
emerge as good candidates to produce cellulose whiskers for applications such as in reinforcements to polymer composites. Despite some studies carried out on the development of new composite materials based on these fibers (Abd Halip et al. 2019; Bezerra et al. 2017; Bezerra et al. 2016; Silva et al. 2016), their cellulose nanocrystals still remains to be developed.

In addition to the development of new materials, there is an incessant interest in the rational exploration and use of sources from the Brazilian semiarid, such as native plants, to deal with social and ecological adversities (Dos Santos et al. 2009), since this can be a way of helping develop and add value to Caatinga's biome, the most densely populated semiarid area in the world (Cunha et al. 2015). Moreover, despite the problems associated with long drought periods in the Caatinga (Cunha et al. 2015), caroá and macambira are totally adapted to live in such harsh conditions, which could also benefit its economy.

In this work, cellulose nanocrystals were extracted through two pre-treatments (bleaching and mercerization) followed by hydrolysis with sulfuric acid from caroá and macambira fibers. Effect of sample preparation and extraction on morphology and thermal properties of nanocrystals were investigated aiming at their use as reinforcements to nanocomposites.

\section{Experimental}

\subsection{Materials}

Caroá and macambira fibers were collected at the Caatinga biome in Nova Palmeira, Paraiba State, Brazil. Reagent grade chemicals used for the whole process were the follow: mercerization (Sodium hydroxide) was purchased from Vetec Chemistry (Rio de Janeiro, Brazil); sodium chlorite and glacial acetic acid, used in the delignification step were purchased, respectively from Sigma-Aldrich (São Paulo, Brazil) and Química Nova (São Paulo, Brazil). Sulfuric acid used in nanowhisker hydrolysis was purchased from Química Nova (São Paulo, Brazil). The chemicals were used as purchased, with no further purification performed.

\subsection{Fiber treatment}

Fibers were first treated by dispersing in a $10 \%$ Sodium hydroxide solution under constant stirring at $80^{\circ} \mathrm{C}$ for a period of $2 \mathrm{~h}$ according to the literature (Corradini et al. 2006; Rosa et al. 2010) and based in previous analyses. This sample was filtered and washed with water at room temperature to reach neutral $\mathrm{pH}$. Then, the fibers were dried at $50^{\circ} \mathrm{C}$ for $24 \mathrm{~h}$ in an air-circulation oven and subsequently submitted to bleaching process, which was carried out in two steps, as reported in the literature (Wise et al. 1946). Mercerization process is found to be a way to modify cellulose. In native cellulose, each basic fibril in the inner structure contais chains of the same polarity, as reported elsewhere. On the other hand, after the mercerization process, the regenerated fibers show chains of alternating polarity, also antiparallel chains. While swelling in alkali solution, microfibrils of opposite polarity may coalesce, thus allowing the chains do adopt an arrangement in an antiparallel distribution. This is one of requested distribution to form cellulose II (Revol et. Al. 1987). 
The first step consists of a reaction carried out under vigorous stirring at $65^{\circ} \mathrm{C}$ for $1 \mathrm{~h}$. Bleached fibers were then washed, vacuum filtered and dried in an air-circulation oven for $6 \mathrm{~h}$. The second bleaching step consisted in soaking dry fibers in a $0.05 \mathrm{~N}$ nitric acid solution and heating up to $70^{\circ} \mathrm{C}$ for $1 \mathrm{~h}$. The treated sample was then sieved in a 100-mesh size sieve and washed with water until reaching a neutral pH.

Due to the amount of lignin observed in previous tests, complete removal of non-cellulosic components was difficult. Therefore, Macambira fibers were treated twice, i.e., mercerization and bleaching were carried out twice. The combination of mercerization/bleaching act to partially remove lignin from cellulose fibers, thus resulting mainly in cellulose (llyas et al. 2018).

\subsection{Acid hydrolysis}

Treated caroá and macambira fibers were hydrolyzed to obtain cellulose nanocrystals using an aqueous solution of $\mathrm{H}_{2} \mathrm{SO}_{4} 60 \mathrm{wt}$.\%. The hydrolysis process occurred using a pre-heated solution at $45^{\circ} \mathrm{C}$ for 60 min and under vigorous stirring (Xing et al. 2018). After which, samples were quenched in cold water, and the resulting dispersion was centrifuged (Centurion Scientific K3 Series, USA) at 3000 rpm for 15 min. This process was performed three times. The centrifuged concentrated suspension was dialyzed with distilled water in a dialysis tubing (Spectrapor 2; MWCO 12,000-14,000; $45 \mathrm{~mm}$ flat width) for about $72 \mathrm{~h}$ until a neutral $\mathrm{pH}$ was achieved, and the nanocrystals aqueous suspension was stored at $5-10^{\circ} \mathrm{C}$ in a refrigerator (see Scheme 1).

\subsection{Fiber and nanocrystal characterization}

\subsubsection{Chemical Analysis}

The fibers and whiskers were chemically analyzed according to the Technical Association of the Pulp and Paper Industry (TAPPI) standard procedure to determine lignin (TAPPI T13m-54), and holocellulose and cellulose(TAPPI T9-m) (Carrier et al. 2011; TAPPI 1949; TAPPI 1983). Untreated and treated fibers with $10 \% \mathrm{NaOH}$ solution (mercerized) were dried in an air-circulating oven for $24 \mathrm{~h}$ at $60^{\circ} \mathrm{C}$ before characterization. To determine lignin content, a mass $(\mathrm{L} 1)$ of $5 \mathrm{~g}$ of fibers was placed in a $50 \mathrm{~mL}$ Erlenmeyer flask. After that, $20 \mathrm{~mL}$ of $72 \%$ sulfuric acid ( $\mathrm{v} / \mathrm{v})$ were added and kept under constant stirring at room temperature for $24 \mathrm{~h}$. This suspension $(500 \mathrm{~mL})$ was then transferred into a round bottom flask and $280 \mathrm{~mL}$ of distilled water were added at room temperature. The system was kept under stirring for 4 $\mathrm{h}$ and then the suspension obtained was filtered in a sintered funnel plate followed by drying in an aircirculating oven for $12 \mathrm{~h}$ at $70^{\circ} \mathrm{C}$. Triplicate samples were weighed (L2) and the lignin content determined as:

$$
\% \operatorname{Ligin}=\left(\frac{L 3-L 2}{L 1}\right) * 100 \%
$$

where L3 is the quantity L1 with the mass of the paper filter. 
Holocellulose content was determined by adding $120 \mathrm{~mL}$ distilled water, $1 \mathrm{~mL}$ acetic acid and $2.5 \mathrm{~g}$ sodium chlorite in an Erlenmeyer containing $5 \mathrm{~g}$ of fibers $(\mathrm{H} 1)$, followed by continuous stirring for $3 \mathrm{~h}$ at $70^{\circ} \mathrm{C}$. At each $1 \mathrm{~h}$ interval, $1 \mathrm{~mL}$ acetic acid and $2,5 \mathrm{~g}$ sodium chlorite were added to keep the reaction occurring. After completion, fibers were filtered, dried at $70^{\circ} \mathrm{C}$ for $12 \mathrm{~h}$ and weighed $(\mathrm{H} 2)$. $\mathrm{H} 3$ was determined weighting paper filter together with $\mathrm{H} 1$. All analyses were performed in triplicate and the average value reported.

$$
\% \text { Holocellulose }=\left(\frac{H 3-H 2}{H 1}\right) * 100 \%
$$

Cellulose content was determined by subtracting the a-cellulose part from the holocellulose content. Thus, the holocellulose sample was dried in an air-circulation oven at $60^{\circ} \mathrm{C}$ by $24 \mathrm{~h}$. After that, $1 \mathrm{~g}$ holocellulose was weighed and $25 \mathrm{~mL} \mathrm{NaOH} 17.5 \mathrm{wt}$ \% added. After 20 min of reaction, $40 \mathrm{~mL}$ of water were added, and the sample was filtered in a plate sintered funnel with pre-weighed paper filter (C3). This sample was washed to neutral $\mathrm{pH}$ and then dried at $60^{\circ} \mathrm{C}$ for $8 \mathrm{~h}$. Cellulose was then weighed (C2). Analyses were performed in triplicate and the average value reported.

$$
\% \text { Cellulose }=\left(\frac{C 3-C 2}{C 1}\right) * 100 \%
$$

\subsubsection{Morphological analyses}

Fiber morphology before and after each treatment was analyzed using a Leo-1430 Carl Zeiss scanning electron microscope (SEM) operating at $10-20 \mathrm{kV}$. Prior to SEM analyses, specimens were gold-coated for $60 \mathrm{~s}$ in a K550X Emitech sputter coater.

Nanocrystal morphology was investigated using a model SPM-9600 atomic force microscope (AFM) (Shimadzu, Japan). Crystal dimensions were measured using a Gwyddion v 2.31 An SPM data visualization and analysis tool. A drop of a diluted aqueous suspension $(1 \mathrm{~g} / 400 \mathrm{~mL})$ of nanocrystal was deposited onto a freshly cleaved mica surface and allowed to dry in a desiccator for $24 \mathrm{~h}$. At least 20 crystals were selected to determine the average length and width for the calculation of the aspect ratio.

\subsubsection{Thermogravimetric Analysis}

Thermogravimetric analyses (TGA) of untreated and treated fibers were carried out in a Shimadzu DTG$60 \mathrm{H}$ thermogravimetric analyzer to evaluate the effect of each step of treatment (mercerization, bleaching and acid extraction). Samples were scanned over a temperature range of 30 to $600^{\circ} \mathrm{C}$ at a heating rate of $10^{\circ} \mathrm{C} / \mathrm{min}$ under argon atmosphere at a continuous flow rate of $50 \mathrm{~mL} / \mathrm{min}$.

\section{Results And Discussion}


Fiber composition is shown in Table 1. After mercerization, a reduction in lignin content and an increase in cellulose content were observed, combined with an accentuated loss in mass. Untreated fibers exhibit lignin contents of about $60 \%$ and $70 \%$, for macambira and caroá respectively, which is significantly high as compared with some lignocellulosic fibers such as coconut, whose lignin content usually ranges from 37 to 44\% (Fahma et al. 2011; Rosa et al. 2010; Rosa et al. 2009).

Lignin content of macambira fibers decreased about $70 \%$, from $59.8 \%$ to $18.4 \%$, after alkaline treatment that removed the amorphous phase of fibers, as lignin, polysaccharides and some other components such as wax (Hashim et al. 2012; Kim and Netravali 2010; Wang et al. 2003). Cellulose content, on the other hand, increased from about $28.6 \%$ to $74.5 \%$ with the same treatment. This did not indicate that cellulose increases in absolute values, but in the percentage of cellulose in relation to the total of sample.

Lignin content in caroá reduced from $69.1 \%$ to $31 \%$ after mercerization, followed by bleaching and a second mercerization. This fiber has a large percentage of amorphous material, which requires a harsher treatment. Three bleaching stages were carried out to fully remove lignin and other amorphous components. The reaction yield shows a loss of $35 \mathrm{wt}$ \% for caroá fibers. The relatively cellulose content increased from $26.9 \%$ to $56.9 \%$ with alkaline treatments.

Table 1 Contents of lignocellulosic macambira and caroá fibers

\begin{tabular}{|lllll|}
\hline Fiber & \multicolumn{3}{l}{ Fiber composition (\%) } & \\
\cline { 2 - 5 } & Cellulose & Hemicellulose & Lignin & Others \\
\hline $\begin{array}{l}\text { Macambira } \\
\text { before mercerization }\end{array}$ & $28.6 \pm 0.6$ & $2.4 \pm 0.9$ & $59.8 \pm 3.5$ & 9.2 \\
\hline $\begin{array}{l}\text { Macambira } \\
\text { after mercerization }\end{array}$ & $74.5 \pm 1.2$ & $3.4 \pm 0.5$ & $18.4 \pm 0.5$ & 3.7 \\
\hline $\begin{array}{l}\text { Caroá } \\
\text { before mercerization }\end{array}$ & $26.9 \pm 0.9$ & $0.4 \pm 0.1$ & $69.1 \pm 0.5$ & 3.5 \\
\hline $\begin{array}{l}\text { Caroá } \\
\text { after mercerization }\end{array}$ & $56.9 \pm 1.1$ & $8.1 \pm 0.6$ & $31.0 \pm 0.9$ & 4.0 \\
\hline
\end{tabular}

*Others means the difference of absolute values in Table to complete $100 \%$

Caroá and macambira fibers underwent alkaline treatment, followed by bleaching, as described in methods. Differences in morphology can be observed in SEM micrographs (Fig. 1). Non-cellulosic components are observed in untreated fibers, as shown for caroá and macambira. SEM images evidence that fibers were covered with a non-cellulosic and non-fibrous material layer. Through the treatment, mainly after bleaching, fibers exhibit a uniform appearance and a linear arrangement of fibrils as seen in 
the bottom images of Fig.1, which are of bleached fibers. Figure 1 shows that waxes covering fiber surface were removed after treatment.

Lignin is a natural biding agent of cellulose that makes vegetable fibers a complex structure. However, the chemical structure of lignin and cellulose are quite different (Tobimatsu and Schuetz 2019). In this sense, process as mercerization and bleaching act degrading lignin while keeping crystalline domains of cellulose practically intact (llyas et al. 2018) as can be seen in SEM images of Fig.1 and corroborated by the results presented in Table 1.

AFM images of Fig. 2show the morphology of nanocrystals extracted from macambira and caroá fibers. Nanocrystals from caroá fibers had diameters ranging from 31 to $59 \mathrm{~nm}$ and lengths from 203 to 296 $\mathrm{nm}$. Crystals extracted from macambira fibers showed similar average sizes, with diameters ranging from 34 to $51 \mathrm{~nm}$ and lengths between 214 and $262 \mathrm{~nm}$. The results showed that the aspect ratios were $5.3 \pm 1.6$ and $5.2 \pm 0.7$ for of caroá and macambira, respectively. The morphology of caroá and macambira whiskers is presented in Figure 2(a) and (b), respectively. This low aspect ratio, as compared to other natural fibers (Chazeau et al. 1999; Wang et al. 2006), is attributed to the alkaline/bleaching processes that not only removed lignin and other non-cellulosic components, but also may have removed the amorphous regions of cellulose, thus reducing the aspect ratio. In addition, the sulfuric acid extraction also tends to attack cellulose crystals (Li et al. 2009; Visakh et al. 2012; Wang et al. 2006).

\section{Thermogravimetric analysis}

Decomposition of the untreated fibers occurred in several stages, indicating the presence of components which decompose at different temperatures. Thermogravimetric analyses were carried out in untreated and treated fibers. The main difference between thermogravimetric curves of untreated and each treated fiber was the loss over the range of 30 to $100^{\circ} \mathrm{C}$, which has been attributed to moisture uptake. In addition, other differences have been observed for onset temperature. Due to the low decomposition temperatures of hemicellulose and lignin, the mass loss of the original fiber sample started at about $210^{\circ} \mathrm{C}$, with a DTG peak observed at around $350^{\circ} \mathrm{C}$. This thermal event can be associated to pyrolysis of the cellulose. For both cases, it was observed an increase in thermal stability after treatment with sodium hydroxide due to the conversion of cellulose I to cellulose II, which is more thermally stable (Barud et al. 2011; Borsoi et al. 2016).

Table 2 Crystallinity index and T ONSET for caroá and macambira fibers before and after undergoing mercerization, bleaching and acid hydrolysis 


\begin{tabular}{|llll|}
\hline Fiber & Treatment & $\mathrm{I}_{\mathrm{C}}(\%)$ & $\mathrm{T}_{\text {ONSET }}\left({ }^{\circ} \mathrm{C}\right)$ \\
\hline Caroá & Untreated & 47.0 & 257 \\
\cline { 2 - 4 } & Mercerized & 61.1 & 268 \\
\cline { 2 - 4 } & One bleaching step & 61.4 & 280 \\
\cline { 2 - 4 } & Two bleaching steps & 68.1 & 290 \\
\cline { 2 - 4 } & Three bleaching steps & 71.6 & 288 \\
\cline { 2 - 4 } Macambira & Cellulose nanocrystals & 63.8 & 184 \\
\cline { 2 - 4 } & Untreated & 47.1 & 238 \\
\cline { 2 - 4 } & Mercerized & 67.5 & 282 \\
\cline { 2 - 4 } & One bleaching step & 72.6 & 294 \\
\cline { 2 - 4 } & Two bleaching steps & 70.1 & 298 \\
\cline { 2 - 4 } & Cellulose nanocrystals & 69.2 & 185 \\
\cline { 2 - 4 } & & \\
& &
\end{tabular}

Thermal degradation curves for caroá and macambira fibers are presented in Fig. 3. DTG curves are also shown for both samples, in which peaks indicates volatiles loss, chemical transformations and decomposition of analyzed fibers. All caroá samples, except for whiskers, are thermally stable over the region of $100^{\circ} \mathrm{C}$ and $250^{\circ} \mathrm{C}$. This temperature range is typical for processing thermoplastic-based composite materials. Macambira samples, except whiskers, have similar thermal stability, $100-240^{\circ} \mathrm{C}$ for fibers without treatment and $100-280^{\circ} \mathrm{C}$ for treated fibers.

The whiskers exhibited lower thermal stability when compared with untreated fibers and treated with sodium hydroxide and sodium chlorite, as already reported in the literature. (Azeredo et al. 2015; Carrier et al. 2011; Dorez et al. 2014; Moran et al. 2008; Razali et al. 2015; Thakur and Thakur 2014; Yue et al. 2015). These studies have shown that the process used (acid extraction) results in the incorporation of sulfate groups on crystal surface. Such sulfate groups have a catalytic effect on the thermal degradation reactions of cellulose.

In temperatures below $250{ }^{\circ} \mathrm{C}$ for vegetable fibers, the degradation reactions are consistently related to dehydration of water and to the formation of components such as peroxides, which works as catalyzer for cellulose degradation. The zone over the range between 250 and $409^{\circ} \mathrm{C}$ is known as degradation of hemicellulose component and also attributed to the break of crystalline regions of cellulose (De Rosa et al. 2010; Macedo et al. 2020; Yang et al. 2008). This degradation mechanism is quite different in comparison to that in low temperature, being treated as a reaction of fast degradation (Borsoi et al. 2016). From this range of temperature until the end of degradation, hydrogen bonds are destroyed giving rise to an accentuated change in crystallinity, yielding carbonyl and carboxyl groups that promote a considerable acceleration in the degradation of cellulose (Van De Velde and Kiekens 2002). 
In addition, the whiskers have small size and larger contact surface, which facilitates thermal degradation. Whiskers from cellulosic pulp of macambira show similar thermal behavior of caroá samples, with $\mathrm{T}_{\text {onset }}$ at about $180^{\circ} \mathrm{C}$ and mass loss between this temperature and $600^{\circ} \mathrm{C}$.

In general, the partial removing of lignin might be controlled by the treatments of mercerization and bleaching, which means the hydrophobicity may also be managed by these treatments as our group has previously reported (Rosa et al. 2010).

\section{Conclusions}

Cellulose nanocrystals from caroá and macambira fibers were successfully obtained by acid hydrolysis. Mercerization and bleaching were crucial for changing chemical structure and for removing lignin. SEM images show that fibers, after bleaching, exhibit a more uniform appearance, containing linear arrangement of microfibers. The morphological analysis shows the effectiveness of alkaline treatment followed by bleaching, since non-fibrous contents were removed. Crystalline cellulose in the form of whiskers with sizes of 200 to $300 \mathrm{~nm}$ and acicular morphology were obtained after acid hydrolysis as confirmed by AFM. The chemical analysis of fibers has shown the results indicated content of cellulose comparable to other natural sources of cellulose crystals. Caroá and macambira nanocrystals are less thermally stable than microfibers due to the reduced crystal size and a larger surface area, besides the sulfate groups introduced on cellulose surface that act as catalyst for degradation. Overall, this study showed potential caroá and macambira as a source of cellulose whiskers with promising potential in applications as reinforcements to nanocomposites. In addition, these fibers showed high amount of lignin, which can be partially removed by the combination of mercerization/bleaching steps to tailor whiskers hydrophilicity towards a series of polar and non-polar polymer matrices.

\section{Declarations}

\section{Acknowledgements}

Authors are thankful to CAPES (Brazilian coordination for the improvement of higher education personnel) for the scholarship support of the author Murilo J. P. Macedo and CNPq (Brazilian research council) for providing the funds for this research.

\section{References}

1. Abd Halip J, Hua LS, Ashaari Z, Tahir PM, Chen LW, Uyup MKA (2019) Effect of treatment on water absorption behavior of natural fiber-reinforced polymer composites. In: Mechanical and Physical Testing of Biocomposites, Fibre-Reinforced Composites and Hybrid Composites. Elsevier, pp 141-156

2. Azeredo HMC, Imam SH, de Maria Figueirêdo CB, do Nascimento DM, Rosa MF (2015) Nanocrystalline Cellulose from Coir Fiber: Preparation, Properties, and Applications. In: Handbook of Polymer Nanocomposites. Processing, Performance and Application. Springer, pp 15-26 
3. Barud HS, Ribeiro CA, Capela JM, Crespi MS, Ribeiro SJ, Messadeq Y (2011) Kinetic parameters for thermal decomposition of microcrystalline, vegetal, and bacterial cellulose Journal of thermal analysis and calorimetry 105:421-426

4. Bezerra AFC, Cavalcanti WS, Lima AGBd, Souza MJd, Porto TRN (2017) Unsaturated polyester composite reinforced with Caroá fiber (Neoglaziovia Variegate): water sorption and mechanical properties Matéria (Rio de Janeiro) 22

5. Bezerra AFC, De Carvalho LH, Cavalcanti WS, Barbosa AG (2016) Mechanical behavior of composites reinforced with fibers caroa Fibers and Polymers 17:1908-1915

6. Bledzki A, Gassan J (1999) Composites reinforced with cellulose based fibres Progress in polymer science $24: 221-274$

7. Borsoi C, Zimmernnam MV, Zattera AJ, Santana RM, Ferreira CA (2016) Thermal degradation behavior of cellulose nanofibers and nanowhiskers Journal of Thermal Analysis and Calorimetry 126:1867-1878

8. Carrier M, Loppinet-Serani A, Denux D, Lasnier J-M, Ham-Pichavant F, Cansell F, Aymonier C (2011) Thermogravimetric analysis as a new method to determine the lignocellulosic composition of biomass and Bioenergy 35:298-307

9. Chazeau L, Paillet M, Cavaille J (1999) Plasticized PVC reinforced with cellulose whiskers. I. Linear viscoelastic behavior analyzed through the quasi-point defect theory Journal of Polymer Science Part B: Polymer Physics 37:2151-2164

10. Colom X, Carrasco F, Pages P, Canavate J (2003) Effects of different treatments on the interface of HDPE/lignocellulosic fiber composites Science and Technology 63:161-169

11. Corradini E, de Morais LC, Rosa MF, Mazzetto SE, Mattoso LHC, Agnelli JAM (2006) A Preliminary Study for the Use of Natural Fibers as

12. Reinforcement in Starch-Gluten-Glycerol Matrix Macromolecula Symposia 245:558-564

13. Cunha A, Alvalá RC, Nobre CA, Carvalho MA (2015) Monitoring vegetative drought dynamics in the Brazilian semiarid region Agricultural and forest meteorology 214:494-505

14. De Rosa IM, Santulli C, Sarasini F (2010) Mechanical and thermal characterization of epoxy composites reinforced with random and quasi-unidirectional untreated Phormium tenax leaf fibers Materials \& Design (1980-2015) 31:2397-2405

15. Dorez G, Ferry L, Sonnier R, Taguet A, Lopez-Cuesta J-M (2014) Effect of cellulose, hemicellulose and lignin contents on pyrolysis and combustion of natural fibers Journal of Analytical and Applied Pyrolysis 107:323-331

16. Dos Santos LL, Ramos MA, Da Silva SI, De Sales MF, De Albuquerque UP (2009) Caatinga ethnobotany: anthropogenic landscape modification and useful species in Brazil's semi-arid Northeast Economic Botany 63:363

17. Fahma F, Iwamoto S, Hori N, Iwata T, Takemura A (2011) Effect of pre-acid-hydrolysis treatment on morphology and properties of cellulose nanowhiskers from coconut husk Cellulose 18:443-450 
18. Fiore V, Di Bella G, Valenza A (2015) The effect of alkaline treatment on mechanical properties of kenaf fibers and their epoxy composites Part B: Engineering 68:14-21

19. Hashim MY, Roslan MN, Amin AM, Zaidi AMA, Ariffin S (2012) Mercerization treatment parameter effect on natural fiber reinforced polymer matrix composite: a brief review World academy of science, engineering and technology 68:1638-1644

20. Ilyas R, Sapuan S, Ishak M (2018) Isolation and characterization of nanocrystalline cellulose from sugar palm fibres (Arenga Pinnata) Carbohydrate polymers 181:1038-1051

21. Kim JT, Netravali AN (2010) Mercerization of sisal fibers: effect of tension on mechanical properties of sisal fiber and fiber-reinforced composites Part A: Applied Science and Manufacturing 41:12451252

22. Li R, Fei J, Cai Y, Li Y, Feng J, Yao J (2009) Cellulose whiskers extracted from mulberry: A novel biomass production Carbohydrate Polymers 76:94-99

23. Macedo MJ, Silva GS, Feitor MC, Costa TH, Ito EN, Melo JD (2020) Composites from recycled polyethylene and plasma treated kapok fibers Cellulose 27:2115-2134

24. Medeiros ES, Mattoso LH, Bernardes-Filho R, Wood DF, Orts WJ (2008) Self-assembled films of cellulose nanofibrils and poly (o-ethoxyaniline) Colloid and Polymer Science 286:1265-1272

25. Moran JI, Alvarez VA, Cyras VP, Vázquez A (2008) Extraction of cellulose and preparation of nanocellulose from sisal fibers Cellulose 15:149-159

26. Orts WJ, Shey J, Imam SH, Glenn GM, Guttman ME, Revol J-F (2005) Application of cellulose microfibrils in polymer nanocomposites Journal of Polymers and the Environment 13:301-306

27. Puglia D, Sarasini F, Santulli C, Kenny JM (2017) Manufacturing of Natural Fiber/Agrowaste Based Polymer Composites. In: Green Biocomposites. Springer, pp 125-147

28. Razali N, Salit MS, Jawaid M, Ishak MR, Lazim Y (2015) A Study on Chemical Composition, Physical, Tensile, Morphological, and Thermal Properties of Roselle Fibre: Effect of Fibre Maturity BioResources 10:1803-1824

29. Revol J F, A Dietrich, D A I Goring (1987) Effect of mercerization on the crystallite size and crystallinity index in cellulose from different sources. in: Canadian journal of chemistry 65.8:17241725.

30. Rosa M et al. (2010) Cellulose nanowhiskers from coconut husk fibers: Effect of preparation conditions on their thermal and morphological behavior Carbohydrate Polymers 81:83-92

31. Rosa MF, Chiou Bs, Medeiros ES, Wood DF, Mattoso LH, Orts WJ, Imam SH (2009) Biodegradable composites based on starch/EVOH/glycerol blends and coconut fibers Journal of Applied Polymer Science 111:612-618

32. Sain M, Tjong J, Sobh A, Birat K, Faruk O (2017) Natural Fiber Reinforced Thermoplastic Composites. In: Lightweight and Sustainable Materials for Automotive Applications. CRC Press, pp 1-38

33. Satayanarayana K, Guimarães J, Wypych F (2007) Studies on lignocellulosic fibers of Brazil. Part l: Source, production, morphology, properties and applications Composites Part A: Applied Science and 
Manufacturing 38:1694-1709

34. Silva C, Barbosa de Lima A, da Silva EG, de Andrade TF, da Costa Melo R Water Absorption in CaroáFiber Reinforced Polymer Composite at Different Temperatures: A Theoretical Investigation. In: Diffusion Foundations, 2016. Trans Tech Publ, pp 16-27

35. Spagnol C et al. (2012) Nanocomposites based on poly (acrylamide-co-acrylate) and cellulose nanowhiskers European Polymer Journal 48:454-463

36. Tadmor Z, Gogos CG (2006) Principles of polymer processing. Wiley. com,

37. TAPPI (1949) Papers and Addresses Presented at the Annual Meeting of the Technical Association of the Pulp and Paper Industry: Index. Technical Association of the Pulp and Paper Industry,

38. TAPPI (1983) Technical Association of the Pulp and Paper Industry Journal vol 66. Technical Association of the Pulp and Paper Industry,

39. Teixeira EdM, Bondancia TJ, Teodoro KBR, Corrêa AC, Marconcini JM, Mattoso LHC (2011) Sugarcane bagasse whiskers: extraction and characterizations Industrial Crops and Products 33:6366

40. Thakur VK, Thakur MK (2014) Processing and characterization of natural cellulose fibers/thermoset polymer composites Carbohydrate polymers 109:102-117

41. Tobimatsu Y, Schuetz M (2019) Lignin polymerization: how do plants manage the chemistry so well? Current opinion in biotechnology 56:75-81

42. Van De Velde K, Kiekens P (2002) Thermal degradation of flax: The determination of kinetic parameters with thermogravimetric analysis Journal of Applied Polymer Science 83:2634-2643

43. Visakh $\mathrm{P}$, Thomas S, Oksman K, Mathew AP (2012) Crosslinked natural rubber nanocomposites reinforced with cellulose whiskers isolated from bamboo waste: Processing and mechanical/thermal properties Composites Part A: Applied Science and Manufacturing 43:735-741

44. Wang H, Postle R, Kessler R, Kessler W (2003) Removing pectin and lignin during chemical processing of hemp for textile applications Textile Research Journal 73:664-669

45. Wang Y, Cao X, Zhang L (2006) Effects of cellulose whiskers on properties of soy protein thermoplastics Macromolecular bioscience 6:524-531

46. Wise LE, Murphy M, d'Addieco AA (1946) Chlorite Holocellulose, its Fractionnation and Bearing on Summative Wood Analysis and on Studies on the Hemicelluloses Paper Tr J 122:35

47. Xing L, Gu J, Zhang W, Tu D, Hu C (2018) Cellulose I and II nanocrystals produced by sulfuric acid hydrolysis of Tetra pak cellulose I Carbohydrate polymers 192:184-192

48. Yang Z, Xu S, Ma X, Wang S (2008) Characterization and acetylation behavior of bamboo pulp Wood Science and Technology 42:621-632

49. Yue Y, Han J, Han G, Aita GM, Wu Q (2015) Cellulose fibers isolated from energycane bagasse using alkaline and sodium chlorite treatments: Structural, chemical and thermal properties Industrial Crops and Products 76:355-363 


\section{Scheme}

Scheme 1 is available in the Supplemental Files section

\section{Figures}
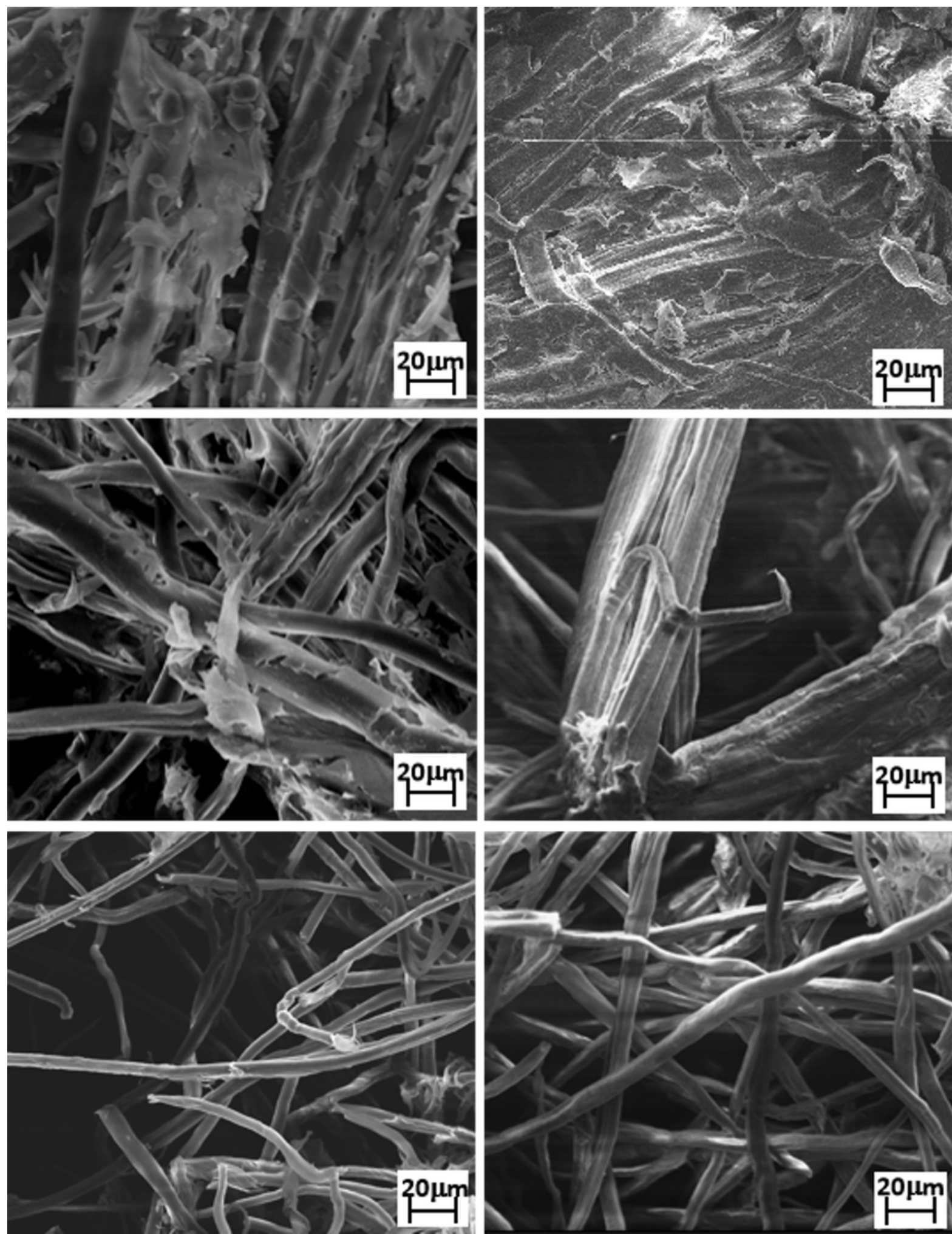

Figure 1 
SEM images of (a) Caroá and (b) Macambira untreated (upper), mercerized (middle) and bleached (bottom), respectively.
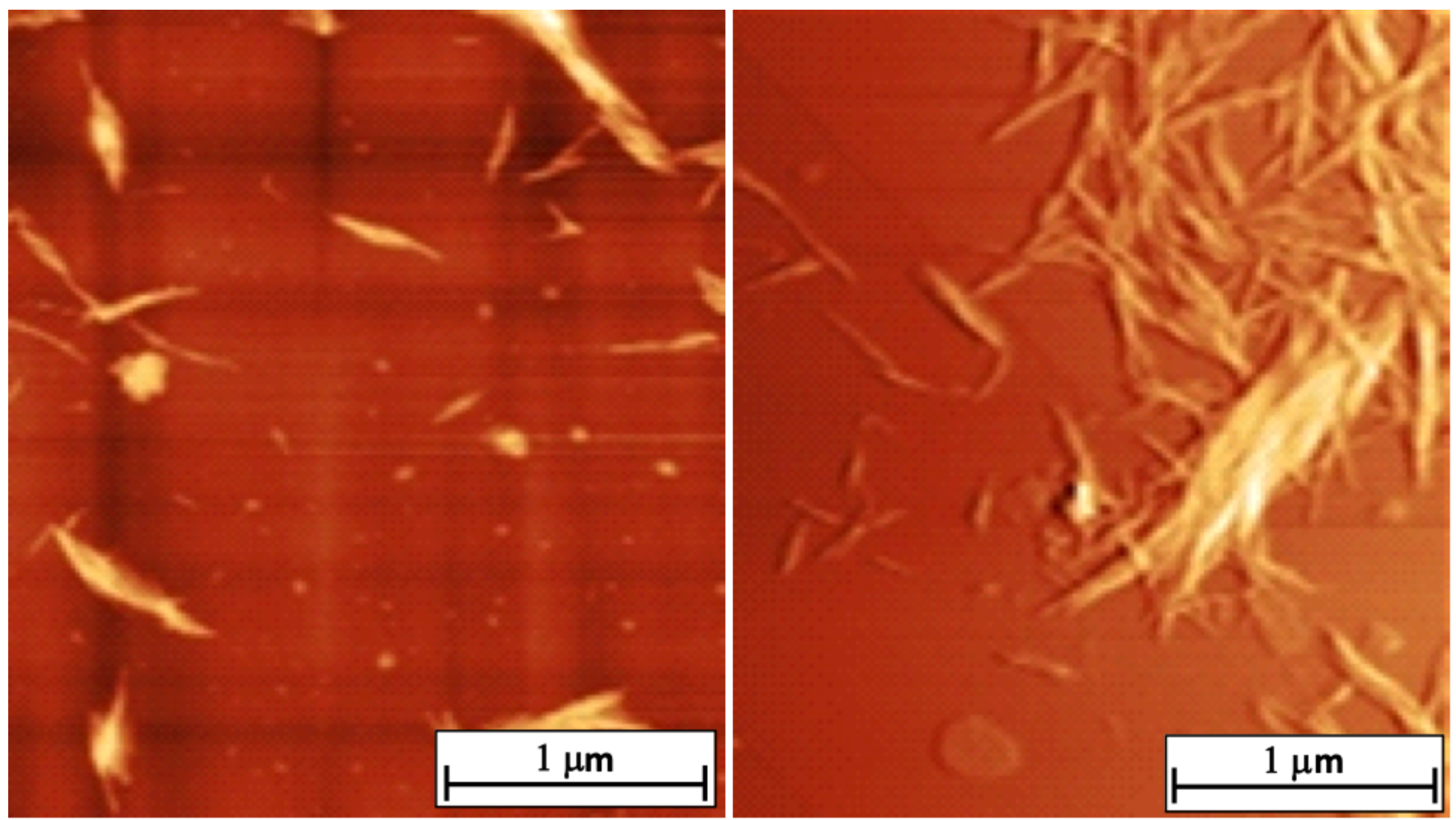

Figure 2

AFM images of whiskers from (a) caroá and (b) macambira extracted at $45^{\circ} \mathrm{C}$ for 60 min. 

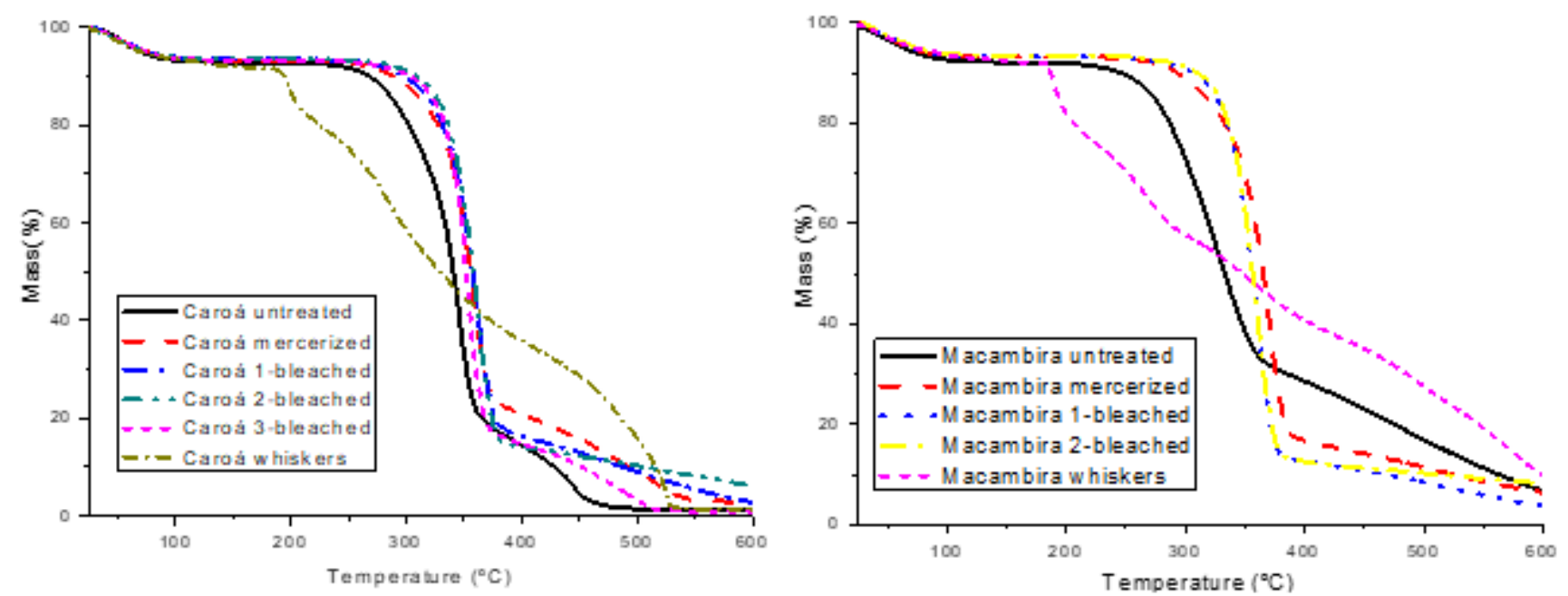

(a)
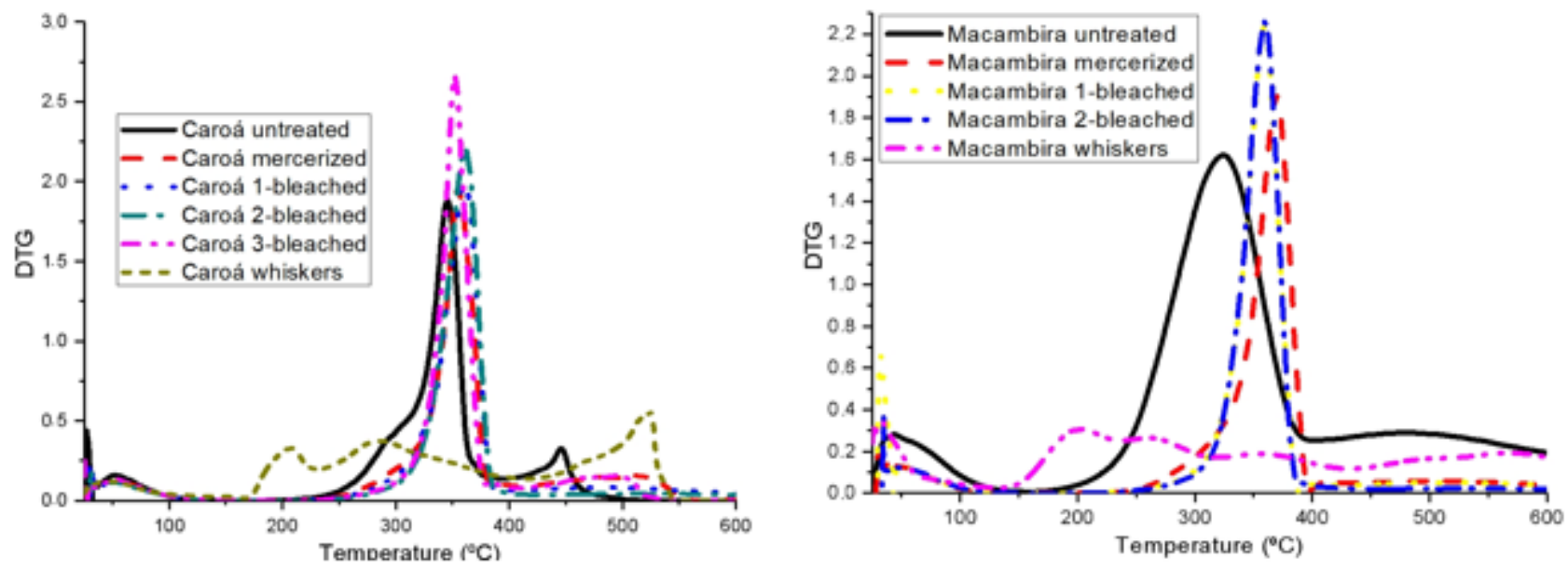

(b)

Figure 3

(a) Thermogravimetry - TG and (b) Derivative Thermogravimetry curves - DTG curves for: caroá and macambira fibers untreated and after treatments

\section{Supplementary Files}

This is a list of supplementary files associated with this preprint. Click to download.

- GraphicalAbstract.pdf

- Scheme1.png 